\title{
Study of Scapular Measurements and Scapular Indices of Andhrapradesh Region
}

\author{
*Dr.M.Krishnaiah ${ }^{1}$, Dr.Nagaraj S ${ }^{2}$, Praveen Kumar M ${ }^{3}$, Dr. Anil R Sherke ${ }^{4}$ \\ 1,2,3,4 Department of Anatomy, Kamineni Institute of Medical Sciences, Narketpally
}

\begin{abstract}
Scapula, the triangular flat bone links the axial skeleton to the appendicular skeleton of upper limb along with clavicle. It shows modifications in its shape in the evolutionary process from quadrupeds to bipeds. Much of the changes have taken place in the infraspinous region. In the present study scapular measurements like breadth, length and infraspinous length are taken and parameters like scapular index, infraspinous index and are calculated which may help in comparative anatomy and defining the race.
\end{abstract}

Key words: Scapula, Scapular breadth, Scapular length, Scapular index, Infraspinous index

\section{Introduction}

Scapula, the important flat bone of the pectoral girdle is situated on the posterior side of the rib cage, overlying ribs 2 through 7. In terms of comparative anatomy, the human scapula represents two bones that have become fused together: the (dorsal) scapula proper and the (ventral) coracoid. ${ }^{1}$ Although, the scapula has attachment of as many as 15 muscles, the shape of the scapula is not due to the forces applied during the development but is a mammalian character. ${ }^{2}$

From the evolutionary point of view scapula has undergone modifications especially in its shape. Scapular index which indicates the relationship of breadth to the length of the bone has been used to note of such modifications. The changes in the scapular shape are more in the infraspinous region than the supra spinous region. Hence infraspinous index relating the breadth of scapula to infraspinous length also has to be taken into account. ${ }^{3}$

The study was carried out for determining the scapular index and infraspinous index by measuring the breadth, length and infraspinous length of scapulae of Andhra Pradesh region.

\section{Materials And Methods}

The study was carried out on the scapulae available at anatomy department of Deccan medical college and KIMS, Narketpally which were collected from dissection of cadavers of Andhra Pradesh region. A total of 50 scapulae of both right and left side were studied.

Instruments :- Osteometric board, vernier caliper, white paper, lead pencil

Method:- A white sheet was pasted to the osteometric board ,the scapula was fixed so that points can be marked over it and errors in the measurement were minimized. Following points ${ }^{4}$ were marked on that white sheet as shown in fig 1 and 2.

$\mathrm{A}=$ Point of intersection of spine of scapula to the medial border (fig2)

$\mathrm{B}=$ Middle of the outer border of the Glenoid cavity (fig2)

$\mathrm{C}=$ Summit of the superior angle (fig2)

$\mathrm{D}=$ Summit of the inferior angle(fig2)

Fig 1 Showing method of marking points

D

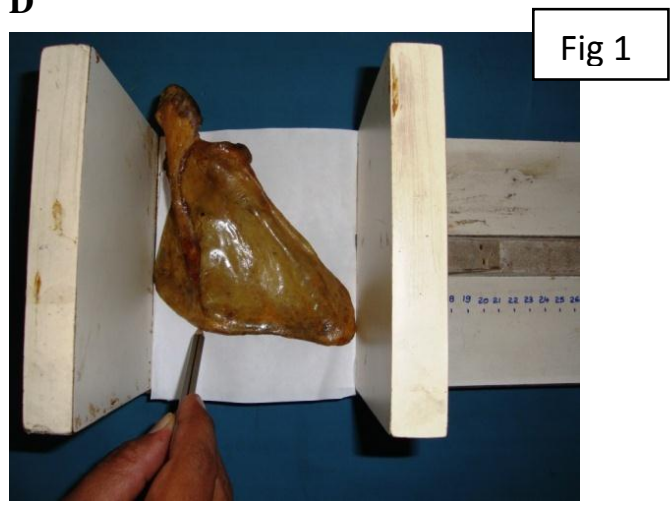

Fig 2 Showing the points $\mathrm{A}, \mathrm{B}, \mathrm{C}$ and

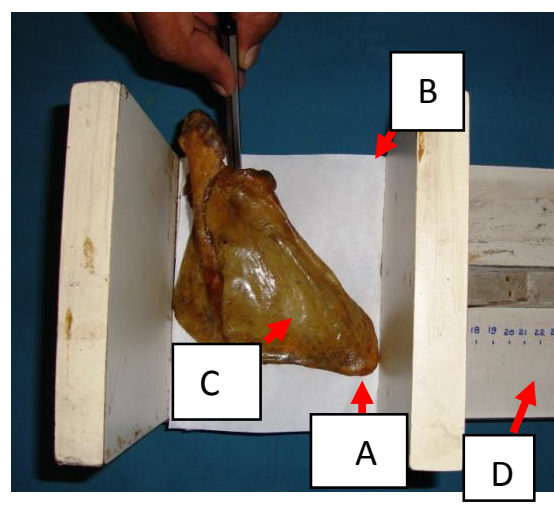

Fig 2 
Scapular breadth is taken as the distance between the points A and B. The Scapular length is taken as the distance between points $C$ and $D$. Infraspinous length is taken as the distance between points A and D. All the measurements taken with the help of vernier caliper in millimeters.

Using these readings scapular index and infraspinous index are calculated as follows

Scapular Index $=($ Breadth X100)/ Length

Infraspinous Index $=($ Breadth X100 $) /$ Infraspinous length

Data was analysed with Microsoft excel and results were tabulated.

A total of 50 scapulae were studied.

\section{Results}

Table 1 showing distribution of scapula as per its breadth

$\mathrm{N}=50$

\begin{tabular}{|l|l|l|}
\hline $\begin{array}{l}\text { Breadth } \\
\text { in mm }\end{array}$ & No of Scapulae & Percentage (\%) \\
\hline $90-95$ & 3 & 6 \\
\hline $95-100$ & 3 & 6 \\
\hline $100-105$ & 13 & 26 \\
\hline $105-110$ & 20 & 40 \\
\hline $110-115$ & 11 & 22 \\
\hline
\end{tabular}

In the present study, the breadth of scapula was ranging from $90.3 \mathrm{~mm}$ to $113.3 \mathrm{~mm}$. The mean and SD were 105.6 and 5.08 respectively. The breadth range of $105 \mathrm{~mm}$ to $110 \mathrm{~mm}$ had the maximum number of scapulae while the minimum number were noted in the 90 to 100 range

$\mathrm{N}=50$

Table 2 showing distribution of scapula as per its length

\begin{tabular}{|l|l|l|}
\hline Length & No. of Scapulae & Percentage (\%) \\
\hline $115-125$ & 6 & 12 \\
\hline $125-135$ & 4 & 8 \\
\hline $135-145$ & 17 & 34 \\
\hline $145-155$ & 16 & 32 \\
\hline $155-165$ & 5 & 10 \\
\hline $165-175$ & 2 & 4 \\
\hline
\end{tabular}

The mean length of the scapula and SD observed were $143.28 \mathrm{~mm}$ and 11.44 respectively. Maximum number of scapulae was in the range of $135 \mathrm{~mm}$ to $145 \mathrm{~mm}$ while least number was in the $165 \mathrm{~mm}$ to $175 \mathrm{~mm}$ range.

$\mathrm{N}=50$

Table 3 showing distribution of scapula as per scapular index [(Breadth/length) X100]

\begin{tabular}{|l|l|l|}
\hline S Index & No. of Scapulae & Percentage (\%) \\
\hline $65-68$ & 3 & 6 \\
\hline $68-71$ & 2 & 4 \\
\hline $71-74$ & 26 & 52 \\
\hline $74-77$ & 13 & 26 \\
\hline $77-80$ & 4 & 8 \\
\hline $80-83$ & 2 & 4 \\
\hline
\end{tabular}

The correlation between breadth and length of scapula is expressed as scapular index which was in the range of $67.16 \mathrm{~mm}$ to $80.63 \mathrm{~mm}$. Mean and standard deviation were $73.99 \mathrm{~mm}$ and 4.63 respectively. Maximum number of scapula were found in the range of $71 \mathrm{~mm}$ to $74 \mathrm{~mm}(52 \%)$ followed by $74 \mathrm{~mm}$ to $77 \mathrm{~mm}(26 \%)$ followed by $77 \mathrm{~mm}$ to $80 \mathrm{~mm}(8 \%)$, followed by $65 \mathrm{~mm}$ to $68 \mathrm{~mm}(6 \%)$, while only 2 each $(4 \%)$ were in the range of $68 \mathrm{~mm}$ to $71 \mathrm{~mm}$ and $80 \mathrm{~mm}$ to $83 \mathrm{~mm}$ range. 
Table 4 showing distribution of scapula as per Infraspinous index

[(Breadth/Infraspinouslength) X100]

$\mathrm{N}=50$

\begin{tabular}{|l|l|l|}
\hline Infraspinous index & No. of Scapulae & Percentage (\%) \\
\hline $93-95$ & 4 & 8 \\
\hline $95-97$ & 15 & 30 \\
\hline $97-99$ & 15 & 30 \\
\hline $99-101$ & 10 & 20 \\
\hline $101-103$ & 4 & 8 \\
\hline $103-105$ & 2 & 4 \\
\hline
\end{tabular}

The correlation between breadth and infraspinous length of scapula is expressed as Infraspinous index which was in the range of $93.09 \mathrm{~mm}$ to $104.28 \mathrm{~mm}$. Mean and standard deviation were $98.33 \mathrm{~mm}$ and 5.86 respectively. Maximum number of scapula were found two groups i.e. in the range of $95 \mathrm{~mm}$ to $97 \mathrm{~mm}$ and $97 \mathrm{~mm}$ to $99 \mathrm{~mm}$ (30\% each) followed by $99 \mathrm{~mm}$ to $101 \mathrm{~mm}(20 \%)$ followed by two groups in range of $93 \mathrm{~mm}$ to $95 \mathrm{~mm}$ and $101 \mathrm{~mm}$ to $103 \mathrm{~mm}$ ( $8 \%$ each) followed by $103 \mathrm{~mm}$ to $105 \mathrm{~mm}(4 \%)$

\section{Discussion}

The scapular length, breadth and indices of Nalgonda region were studied. The current study was compared with various studies carried out on other geographic populations.

Scapular breadth: Mean Scapular breadth was ranging 105.59 with standard deviation of 5.08 in present study, while Flower W H's study of European race showed mean breadth to be 101.42 which is almost correlating with our study. ${ }^{4}$

Scapular length: Mean Scapular length was 143.27 with standard deviation of 11.44 in present study, while Flower WH's study of European race showed mean breadth to be $155.44 \mathrm{~mm}$. Thus the scapular length of European region is higher than that of Nalagonda region. ${ }^{4}$

Infraspinous length: Mean Infraspinous length was ranging $107.71 \mathrm{~mm}$ with standard deviation of 7.6 in present study, while Flower W H's study of European race showed mean breadth to be $113.46 \mathrm{~mm}$ which is nearing to the present study. ${ }^{4}$

Scapular index: Mean scapular index observed in present study was $73.99 \mathrm{~mm}$ with standard deviation of 4.6. In other studies, the mean scapular index ranged from a minimum of $57.3 \mathrm{~mm}$ in Peruvian population to a maximum of $69.8 \mathrm{~mm}$ in the Andaman region. Thus our study scapular index value is nearer to Andaman region.

Table5 showing scapular index of various populations studied by various authors

\begin{tabular}{|l|l|l|l|l|}
\hline Sl.no & Authorities & $\begin{array}{l}\text { No.of Scapula } \\
\text { observed }\end{array}$ & Race/Region & Mean scapular index \\
\hline 1 & Broca M $1878^{5}$ & 46 & European & 65.91 \\
\hline 2 & ${\text { Broca M } 1878^{5}}^{5}$ & 2 & Peruvian & 68.02 \\
\hline 3 & Broca M $1878^{5}$ & Negro & 68.16 \\
\hline 4 & Flower WH $1879^{4}$ & 50 & European & 65.2 \\
\hline 5 & Flower WH $1879^{4}$ & 200 & Peruvian & 57.3 \\
\hline 6 & Flower WH $1879^{4}$ & 2 & Negro & 71.7 \\
\hline 7 & Flower WH $1879^{4}$ & Australian & 68.9 \\
\hline 8 & Flower WH $1879^{4}$ & Andaman & 69.8 \\
\hline 9 & Turner $1893^{6}$ & 12 & European & 64.9 \\
\hline 10 & Present study 2014 & 21 & Nalagonda & 73.99 \\
\hline
\end{tabular}

Infraspinous index: Mean infraspinous index observed in present study was 98.33 with the standard deviation of 5.86 while this index varies from 75.1 in Peruvian race to 100.9 in Negroes. Present study infraspinous index was more corresponding with that of Negro race.

Table6 showing Infraspinous index of various populations studied by various authors

\begin{tabular}{|l|l|l|l|l|}
\hline Sr.no & Authorities & $\begin{array}{l}\text { No. of Scapula } \\
\text { observed }\end{array}$ & Race/region & $\begin{array}{l}\text { Mean infra spinous } \\
\text { index }\end{array}$ \\
\hline 1 & Broca M $1878^{5}$ & 46 & European & 87.79 \\
\hline 2 & Broca M $1878^{5}$ & 2 & Peruvian & 91.74 \\
\hline 3 & Broca M $1878^{5}$ & 50 & Negro & 93.88 \\
\hline 4 & Flower WH $1879^{4}$ & 200 & European & 89.4 \\
\hline
\end{tabular}


Study Of Scapular Measurements And Scapular Indices Of Andhrapradesh Region

\begin{tabular}{|l|l|l|l|l|}
\hline 5 & Flower WH $1879^{4}$ & 2 & Peruvian & 75.1 \\
\hline 6 & Flower WH $1879^{4}$ & 6 & Negro & 100.9 \\
\hline 7 & ${\text { Flower WH } 1879^{4}}_{4}^{4}$ & 12 & Australian & 92.5 \\
\hline 8 & ${\text { Flower WH } 1879^{4}}^{6}$ & 21 & Andaman & 92.7 \\
\hline 9 & Turner $1893^{6}$ & European & 89.4 \\
\hline 10 & Present study & 25 & Nalagonda & 98.33 \\
\hline
\end{tabular}

\section{Conclusion}

The scapular measurements can be used for comparative anatomy and manufacturing of prosthetic products and surgical procedures such as prosthetic positioning. The present study showed mean scapular index to be $73.99 \mathrm{~mm}$ (range $=67.16 \mathrm{~mm}$ to $80.63 \mathrm{~mm}$ ) and mean Infraspinous index to be 98.23 (range $=93.69 \mathrm{~mm}$ to $104.38 \mathrm{~mm}$ ). These two indices are nearer to studies of Andaman population.

Further in depth studies about scapular measurements, including radiological may help in determining the race just by using the indices.

\section{References}

[1]. R.M.H Mc Minn, Last's Anatomy., $9^{\text {th }}$ ed. UK edition: Churchill Livingstone, 2009. P. 53

[2]. Barden CR. Skeleton. American Journal of Anatomy 1905; 4:265-73.

[3]. Inman, Saunders JB, Abbot. Observation on the junction of the shoulder joint. Journal of bone \& joint surgery 1944; 1:30.

[4]. Flower WH, Garson JG. The scapular index as a race character in man. Journal of anat physiol 1879; 14(1): 13-17.

[5]. The scapular index as a race character in man. Available from: http://19thcenturyscience.org/HMSC/HMSC-Reports/Zool47/PDFpages/0082.pdf. Accessed May 28th, 2014.

[6]. Transactions and proceedings of the Royal society of New Zealand 1868-1961. Available from: http://rsnz.natlib.govt.nz/volume/rsnz 26/rsnz 26 00 000470.html Accessed May 28th, 2014. 